\title{
PERMBELAJARAN PPKn DENGAN VALUE CLARIFICATION TECHNIQUE BERBANTUAN ROLE PLAYING TERHADAP KETERAMPILAN INTELEKTUAL SISWA SMA
}

\author{
Akhwani \\ Universitas Nahdlatul Ulama Surabaya \\ e-mail: akhwani@unusa.ac.id
}

\begin{abstract}
Abstrak: Tujuan penelitian ini adalah untuk menganalisis efektivitas pembelajaran PPKn dengan value clarification technique (VCT) berbantuan role playing terhadap keterampilan intelektual siswa SMA. Penelitian ini merupakan penelitian eksperimen semu yang didesain melalui kelompok eksperimen dan kelompok kontrol. Kelompok eksperimen menggunakan pembelajaran PPKn dengan VCT berbantuan role playing, sementara kelompok kontrol hanya menggunakan VCT. Pengumpulan data menggunakan observasi. Data dianalisis menggunakan bantuan SPSS 16 for Windows melalui uji $t$-test dengan taraf signifikansi $5 \%$. Hasil penelitian membuktikan bahwa nilai signifikansi lebih kecil dari $0,05(\mathrm{p}=0,006<0,05)$, sementara nilai t hitung lebih besar dari nilai t tabel $(2,849>1,99)$. Dengan demikian pembelajaran PPKn dengan VCT berbantuan role playing efektif dalam mengembangkan keterampilan intelektual siswa SMA.
\end{abstract}

Kata kunci: value clarification technique, role playing, keterampilan intelektual

Abstract: The purpose of this research was to analyze the effectiveness of PPKn learning used value clarification technique (VCT) which was combined by role playing, on intellectual skills of high school students. This research is a quasi-experimental research designed through experimental group and control group. The experimental group used PPKn learning with VCT-combined by role playing, while the control group only used VCT. Data collection used observation. Data were analyzed using SPSS 16 for windows through t-test with significance level of 5\%. The research finding showed that the significance value was less than $0.05(p=0.006<0.05)$, while the tvalue was greater than $t$ table (2.846> 1.99). Thus the learning of PPKn with value clarification technique-combined by role playing was effective in developing intellectual skill of high school students

Keywords: value clarification technique, role playing, intellectual skills

\section{PENDAHULUAN}

Pendidikan Pancasila dan Kewarganegaraan (PPKn) merupakan mata pelajaran yang memiliki peran penting dalam rangka membentuk warga negara yang unggul dan berkualitas. PPKn lebih dari sekedar bidang studi, PPKn mengambil peran positif untuk mempersiapkan warga negara dan peranannya di dalam masyarakat. Mempersiapkan generasi muda yang baik sama halnya dengan menanam kesejahteraan untuk masa de- pan, karena generasi muda adalah cerminan masa datang yang perlu mendapat perhatian lebih, jika tidak dipersiapkan, maka generasi yang muncul di masa mendatang adalah generasi apatis, egois, tidak menyadari akan hak dan kewajiban sebagai warga negara.

Pendidikan Kewarganegaraan (PKn) bermaksud untuk merangsang partisipasi aktif dalam masyarakat madani (Civil Society) di dalam suatu sistem demokrasi konstitusional (Zuchdi. 2011: 358). Partisipasi dan integrasi dari warga negara 
menjadi dasar yang sangat penting untuk menjadi demokrat sejati. Warga negara yang aktif dan terintegrasi secara sosial tidaklah dilahirkan, tetapi diciptakan atau diproduksi dalam suatu proses sosialisasi. Perlu adanya upaya yang serius untuk mewujudkan warga negara yang partisipatif.

The National Standards for Civic and Civic Framework for 1988 National Assessment of Educational Progress (NAEP) menyusun dua komponen yang harus dimiliki anak dalam membentuk keterampilan warga negara (civic skill). Kedua komponen tersebut yakni keterampilan intelektual dan keterampilan berpartisipasi (Branson, 1998). Keterampilan intelektual merupakan dasar dalam berpartisipasi, artinya siswa akan memiliki keterampilan berpartisipasi setelah ia memiliki keterampilan intelektual yang baik. Oleh karena itu, keterampilan intelektual perlu dimiliki oleh setiap siswa dalam merangsang partisipasi aktif dalam masyarakat madani.

Penelitian yang dilakukan oleh Pusparatri (2012) menyebutkan bahwa penyebab lemahnya keterampilan intelektual siswa dipengaruhi oleh strategi pembelajaran yang digunakan guru dalam kegiatan belajar mengajar. Pernyataan tersebut, mengindikasikan bahwa strategi pembelajaran memiliki peranan penting dalam membentuk keterampilan intelektual anak. Penggunaan model atau metode pembelajaran sangat dibutuhkan untuk melatih keterampilan intelektual siswa. Ada banyak sekali metode, model atau teknik pembelajaran yang dapat dipilih. Salah satunya yaitu value clarification technique (VCT).

VCT merupakan model pembelajaran interaktif yang mengarahkan siswa untuk berpikir kritis. Menurut Oliha dan Audu (2015: 3) "Values clarification is not only important for selfimprovement and well-being but also in interactions with others". Artinya VCT merupakan pembelajaran yang active learning yang mampu merangsang siswa untuk berinteraksi dengan siswa lain. VCT juga mendorong siswa untuk berpikir secara kritis dan sistematis tentang sebuah stimulus yang diberikan (Adisusilo, 2012).

Dalam proses pembelajaran VCT, siswa dihadapkan dalam sebuah stimulus berisi cerita dilema moral. Siswa dihadapkan pada pilihanpilihan yang sulit dan dilematis. Siswa diminta untuk mengambil keputusan secara cepat dan tepat setelah dengan mempertimbangkan risiko yang akan dihadapi. Dalam implementasinya, VCT dapat dipadukan dengan metode lain seperti role playing, video, atau audio untuk memudahkan menerima stimulus.

VCT dengan bantuan role playing merupakan kesatuan yang dinilai lebih unggul daripada VCT berdiri sendiri. Hal ini diperkuat oleh beberapa pendapat ahli tentang role playing. Menurut Agell (2015: 318) role playing memberikan kesempatan peserta didik untuk memperoleh pengetahuan yang mendalam; merangsang kemampuan berargumentasi dan membuat opini; memahami pendapat yang berbeda tentang isuisu sosial ilmiah. Dengan demikian perpaduan VCT dengan role playing memberikan gambaran baru dalam membentuk keterampilan intelektual siswa.

Dengan mencermati permasalahan dan penelitian tersebut peneliti tertarik untuk melakukan penelitian tentang efektivitas pembelajaran PPKn dengan value clarification technique (VCT) berbantuan role playing terhadap keterampilan intelektual siswa SMA. Tujuan dari penelitian ini adalah untuk menganalisis efektivitas pembelajaran VCT dengan bantuan role playing dan VCT tanpa bantuan role playing terhadap keterampilan intelektual siswa SMA. 


\section{TINJAUAN PUSTAKA}

PKn (sebutan yang lebih umum) mengemban misi utama untuk memupuk dan mengembangkan warga negara agar memiliki nilai-nilai patriotisme serta membangun komitmen terhadap nilai-nilai demokratis yang dilandasi oleh komitmen terhadap nilai-nilai kebenaran, kejujuran, kemerdekaan, rasa hormat, dan kebebasan berekspresi (Wahab dan Sapriya, 2011: 5). Misi tersebut tidak dapat terwujud manakala warga negara tidak memiliki pengetahuan, keterampilan dan sikap yang baik.

Dalam pandangan Merphin Panjaitan (TIM ICCE, 2003: 9), PKn adalah pendidikan demokrasi yang bertujuan untuk mendidik generasi muda menjadi warga negara yang demokratis dan partisipatif. Hal ini sejalan dengan pendapat Branson (1998:7) bahwa tujuan dari penyelenggaraan PKn adalah partisipasi yang bermutu baik di tingkat lokal, nasional maupun internasional. Partisipasi yang bermutu dapat dimaknai sebagai sebuah keterampilan warga negara dalam melihat situasi dalam masyarakat, menganalisis secara kritis, serta terlibat dalam pengambilan keputusan baik secara langsung maupun tidak langsung.

Keterampilan intelektual menjadi komponen dasar yang harus dimiliki oleh siswa sebagai bekal dalam berpartisipasi. Dalam implementasinya PKn di Indonesia lebih menekankan pada aspek pengetahuan dibandingkan dengan keterampilan atau sikap (civic competence). Dampaknya adalah siswa menjadi jenuh dan tidak tertarik untuk belajar PKn. Pada ujungnya, ketika siswa sudah tidak tertarik pada pelajaran PKn maka tujuan yang ingin dicapai PKn tidak akan terwujud. Terlebih lagi apabila pembelajaran PKn disampaikan dengan ceramah, maka siswa cenderung bosan dan tidak memperhatikan pelajaran.

\section{Pembelajaran PPKn dengan VCT Berbantuan Role Playing}

Pembelajaran PKn yang inovatif dan kreatif adalah sebuah kebutuhan yang tidak dapat ditawar lagi. Pemilihan metode pembelajaran akan berpengaruh pada hasil yang ingin dicapai. Model pembelajaran harus disesuaikan dengan tujuan yang pembelajaran, karena salah memilih metode akan berdampak pada hasil belajar. Apalagi target yang ingin dicapai adalah keterampilan intelektual. Mengajarkan keterampilan tidaklah sama dengan mengajarkan pengetahuan.

Centre for Indonesian Civic Education (CICE) bekerjasama dengan USIS tahun 2000 merekomendasikan penyusunan dan pengembangan PKn sesuai dengan paradigma baru. Salah satu rekomendasi yang diberikan adalah penggunaan strategi pembelajaran PKn harus mengembangkan kecakapan berpikir kritis, kemampuan mengambil keputusan dan menciptakan pembelajaran aktif melalui diskusi maupun dialog. Dengan mencermati prasyarat tersebut, masih belum diketahui strategi pembelajaran seperti apa yang kehendaki CICE dan USIS. Analisis yang tajam perlu dilakukan untuk mengetahui model pembelajaran yang dimaksud.

Rekomendsi di atas, jika dilihat dari kacamata Typology of Pedagogical Strategies for Civic Education (Print \& Smith, 2000: 104) tampak jelas strategi yang dimaksud. Rekomendasi CICE dab USIS masuk dalam kategori class-based, participative-active pedagogies. Strategi pembelajaran yang masuk dalam kategori tersebut adalah VCT, debat, role playing, cooperative learning, class-parliament, dan group problem solving. Dua dari enam strategi pembelajaran yang ditawarkan Print \& Smith dalam tesisnya yang berjudul Teaching Civic Education for a Civil, Democratic Society in the Asian Region adalah VCT dan Role Playing. 
VCT dalam pandangan Oliha dan Audu (2015: 3) didefinisikan sebagai proses pemberian pengaruh nilai kepada siswa melalui pengambilan keputusan. Siswa dihadapkan tentang suatu permasalahan yang dilematis kemudian dimintai tanggapan dari kondisi apa yang akan dilakukan. Sementara menurut Kirschenbaum (2013) dan Wijayanti (2013), VCT membantu siswa untuk mengklarifikasi nilai-nilai melalui pemecahan masalah, diskusi, dialog, dan presentasi.

Penjelasan di atas mengindikasikan bahwa VCT merupakan model pembelajaran yang erat kaitannya dengan pengambilan keputusan dari permasalahan yang dilematis. Pembelajaran VCT dibungkus melalui dialog, diskusi, debat untuk memecahkan masalah. Keterampilan intelektual sangatlah dibutuhkan untuk dapat memecahkan masalah. Apalagi dalam poses pembelajarannya, dialog dan diskusi sangat membutuhkan keterampilan intelektual. Daya kritis, kemampuan menganalisis, kemampuan mengambil keputusan menjadi tuntutan setiap siswa.

Hal tersebut sejalan pendapat Taniredja (2012) bahwa tujuan VCT adalah untuk melatih siswa mengambil keputusan dari kasus yang dilematis, berpikir secara rasional terhadap permasalahan yang dihadapi, mengukur seberapa jauh tingkat kesadaran anak terhadap nilai yang mendasari siswa serta menanamkan nilai-nilai positif kepada siswa. Dari pendapat tersebut tampak adanya keterkaitan antara VCT dan keterampilan intelektual.

VCT dengan bantuan role playing merupakan perpaduan yang menarik. Keduanya merupakan pembelajaran yang berpusat pada siswa. VCT memiliki beberapa jenis, mulai dari analisis nilai, daftar nilai, games dan lainnya. Jenis VCT yang digunakan adalah VCT games. VCT games dilakukan melalui permainan untuk memberikan kejelasan tentang target yang ingin dicapai. VCT games dipilih karena lebih fleksibel dan dapat dipadukan dengan role playing. Menurut Agell (2015: 32) role playing merupakan pembelajaran aktif yang efektif untuk meningkatkan penguasaan materi.

Langkah pembelajaran PPKn dengan VCT berbantuan role playing hampir seperti langkah VCT pada umumnya. Hanya saja stimulus diberikan melalui permainan sosio drama. Raths, Harmin \& Simon (1978: 28) mengklasifikasi langkah-langkah VCT sebagai berikut.

Choosing 1. Choosing freely

2. Choosing from alternatives

Prizing 3. Choosing thoughtful consideration of the consequences of each alternative

4. Prizings and cherishing

5. Affirming

Acting 6. Acting upon choice

7. Repeating

\section{Keterampilan Intelektual}

Keterampilan intelektual menjadi komponen yang tidak boleh ditinggalkan dalam membentuk warga negara yang baik dan cerdas (smart and good citizenship). Keterampilan intelektual sangat penting dalam rangka membentuk siswa yang mampu menganalisis masalah, memecahkan masalah serta memberikan jalan keluar dari masalah yang timbul. Siswa yang memiliki pengetahuan saja tidak cukup jika tidak dilanjutkan dengan keterampilan intelektual. Dampaknya, pengetahuan hanya akan berhenti pada tataran teori saja.

Filiz \& Yasemin (2014) berpendapat bahwa keterampilan intelektual merupakan cara dalam berpikir secara kritis. Orang yang memiliki keterampilan intelektual adalah orang yang mampu berpikir secara sistematis, logis dan jernih dalam 
menghadapi masalah. Berpikir secara kritis menjadi bagian dari higher order thinking skills (HOTS) kemampuan yang muncul ketika siswa dihadapkan pada suatu masalah yang rumit dan membutuhkan analisis yang tajam. Masalah dalam VCT berupa masalah-masalah yang dilematis dan syarat akan konsekuensi dari sebuah pilihan.

Keterampilan intelektual memiliki makna yang lebih luas dari sebuah pengambilan keputusan. Keterampilan intelektual membutuhkan pengetahuan dasar yang kemudian diolah dianalisis secara serius, teliti dengan mengaitkan beberapa informasi. Buah dari keterampilan intelektual adalah keputusan yang mantap, keputusan yang diambil dengan melihat fakta-fakta dan analisis yang kritis. Keputusan tersebut harus diikuti dengan alasan yang rasional.

Dalam pandangan Alec (2001: 7) ada empat kompetensi untuk mengukur kemampuan berpikir kritis anak. Pertama, yakni analisis yang terdiri dari kemampuan menganalisis dan memfokuskan masalah. Kedua, sintesis yang terdiri dari kemampuan mencari informasi dan mengelaborasikan dengan masalah. Ketiga, yakni interpelasi yang merupakan kemampuan siswa dalam menyampaikan pendapat dan menghargai pendapat yang berseberangan. Keempat, yakni evaluasi yang berkaitan dengan kemampuan siswa dalam memberikan solusi atas permasalahan yang muncul, solusi dipilih secara tepat dengan pertimbangan yang matang.

Pada kesempatan lain Branson (1998: 15) dan Cholisin (2005: 7) membagi komponen keterampilan intelektual menjadi tujuh unsur. Unsur-unsur tersebut adalah mengidentifikasi permasalahan yang muncul; mendeskripsikan atau mengilustrasikan; menjelaskan penyebab terjadinya masalah; menganalisis konsekuensi dan komponen terkait; mengevaluasi dengan mempertimbangkan konsekuensi; mengambil keputusan; dan mempertahankan keputusan dengan mengemukakan argumen dan merespons argumen yang berseberangan.

\section{METODE PENELITIAN}

Penelitian ini merupakan penelitian kuantitatif dengan pendekatan eksperimen semu. Ada dua kelas yang digunakan dalam penelitian, yakni kelas eksperimen dan kelas kontrol. Kelas eksperimen merupakan kelas yang didesain menggunakan pembelajaran PPKn dengan VCT jenis games berbantuan role playing, sementara kelas kontrol hanya menggunakan VCT tanpa bantuan apa pun. Populasi penelitian adalah siswa kelas X SMA Negeri 2 Pati. Sampel diambil menggunakan random cluster karena populasinya setara. Jumlah siswa yang berada pada kelas eksperimen maupun kontrol sebanyak 40 anak $(n=40)$.

Teknik pengumpulan data menggunakan observasi dengan memberikan checklist pada indikator yang diobservasi. Lembar observasi disusun dengan menggunakan skala likert dengan skala 1 sampai 4. Data yang diperoleh kemudian di uji menggunakan $t$-test pada taraf signifikansi 5\%. Analisis data menggunakan bantuan SPSS 16 for windows.

\section{HASIL DAN PEMBAHASAN}

\section{Hasil Penelitian}

Hasil penelitian disajikan dalam bentuk kelas eksperimen dan kelas kontrol. Kelas eksperimen adalah kelas yang menggunakan pembelajaran PPKn dengan VCT berbantuan role playing, sementara kelas kontrol merupakan kelas yang hanya menggunakan VCT saja. Berdasarkan perhitungan dengan bantuan SPSS, diketahui rata-rata keterampilan intelektual siswa pada 
kelas eksperimen sebesar 3,48, skor tertinggi sebesar 4, skor terendah 2,40, median sebesar 3,6, modus sebesar 3,6 dan standar deviasinya sebesar 0,39 .

Melalui data tersebut kemudian dicari interval kelas $(\mathrm{K})$, rentang data $(\mathrm{R})$ dan panjang kelas $(\mathrm{P}) . \mathrm{K}=1+3,3 \log \mathrm{n}$, sehingga diperoleh nilai $\mathrm{K}=6$. Nilai $\mathrm{R}=$ nilai maksimal-nilai minimal, sehingga diperoleh 1,6. Panjang kelas $\mathrm{P}=\mathrm{R} /$ $\mathrm{K}$ sehingga diperoleh angka 0,266. Dengan mengacu pada data tersebut, distribusi frekuensi keterampilan intelektual kelas eksperimen dapat ditampilkan seperti pada Tabel 1.

\section{Tabel 1 Keterampilan Intelektual Kelas Eksperimen}

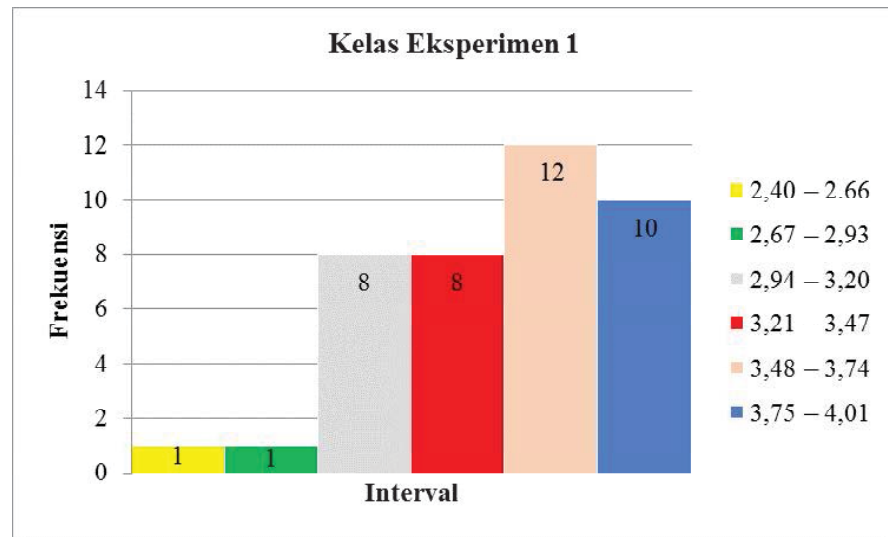

Pada kelas kontrol, yakni pada pembelajaran PPKn yang menggunakan VCT diperoleh nilai rata-rata sebesar 3,23, skor terendah 2,6, skor tertinggi sebesar 3,8, median sebesar 3,2, modus sebesar 3,0 standar deviasinya sebesar 0,38. Dengan menggunakan rumus yang sama, diperoleh hasil kelas interval sama pula yakni 6 kelas, dengan rentang data 1,2 dan panjang kelasnya 0,2 . Dengan mengacu pada data tersebut, distribusi frekuensinya dapat dicermati pada Tabel 2.
Tabel 2 Keterampilan Intelektual Kelas Kontrol

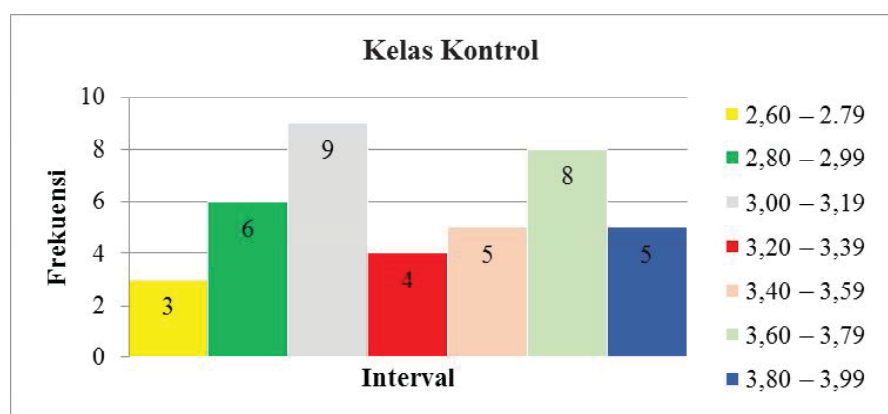

Untuk mengetahui perbandingan antara kelas eksperimen dan kelas kontrol maka data diolah pada skala 1 sampai 4 pada klasifikasi "kurang" sampai "sangat baik", seperti pada klasifikasi Kurikulum 2013. Rentang untuk klasifikasi kurang yakni (0-2,35), cukup (2,40$2,70)$, baik $(2,80-3,19)$, dan sangat baik $(3,20-$ 4). Hasil perbandingannya disajikan pada Tabel 3 berikut.

Tabel 3 Perbandingan Keterampilan Intelektual

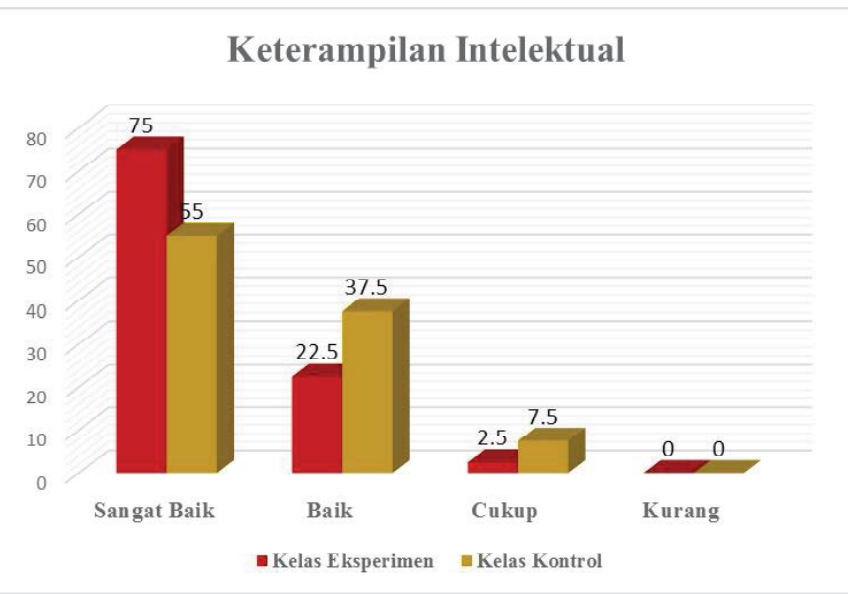

Dengan mencermati data Tabel 3 diketahui bahwa keterampilan pada kelas eksperimen lebih unggul daripada kelas kontrol. Pada klasifikasi "sangat baik", kelas eksperimen lebih unggul dari pada kelas kontrol. Sementara pada kategori 
"baik" kelas kontrol lebih dominan daripada kelas eksperimen. Persamaannya adalah tidak ada siswa yang berada pada kategori kurang. Data tersebut juga mengungkapkan kecenderungan keterampilan intelektual siswa adalah sangat baik.

\section{Uji Hipotesis dan Pembahasan}

Hipotesis (H1) yang diajukan adalah pembelajaran PPKn dengan VCT berbantuan role playing efektif dalam membentuk keterampilan intelektual siswa SMA. T-tes digunakan untuk menguji hipotesis yang diajukan. Hipotesis diterima apabila nilai t hitung lebih besar dari nilai t tabel. Hasil hipotesis juga dapat dilihat dari nilai signifikansinya, jika nilai signifikansinya lebih kecil dari 0,05 maka hipotesis (H1) diterima.

Hasil rangkuman pengujian hipotesis dengan menggunakan T-test menunjukkan data sebagai berikut.

Tabel 4 Pengujian Hipotesis

\begin{tabular}{|l|l|l|l|c|c|}
\hline Data & \multicolumn{1}{|c|}{ Kelas } & T tabel & T hitung & Sig & Ket. \\
\hline Keterampilan & Eksperimen & $\mathrm{df}=78$ & 2,849 & 0,006 & Signifikan \\
\cline { 2 - 3 } Intelektual & Kontrol & 1,99 & & & \\
\hline
\end{tabular}

Data tabel 4 di atas menunjukkan bahwa nilai $\mathrm{T}$ tabel $=1,99$ sementara nilai $\mathrm{T}$ hitungnya 2,849. Data tersebut menunjukkan nilai T hitung lebih besar daripada nilai T tabel $(2,849>1,99)$. Dengan mengacu pada pedoman, maka hipotesis (H1) diterima. Selain itu diketahui nilai signifikansi sebesar 0,006 lebih kecil dari 0,05. Hal ini juga menunjukkan bahwa hipotesis yang menyatakan pembelajaran PPKn dengan VCT berbantuan role playing efektif dalam membentuk keterampilan intelektual siswa SMA diterima.

Efektivitas pembelajaran PPKn dengan VCT berbantuan role playing terhadap keterampilan intelektual siswa SMA tidak lepas dari kedua model tersebut. VCT merupakan model pembelajaran yang mengarahkan siswa untuk berpikir secara mendalam dari sebuah stimulus yang dibungkus dalam sebuah kasus. Kirschenbaum (2013) menyatakan bahwa VCT membantu siswa baik untuk mengaktualisasikan nilai dan keyakinan melalui sebuah kasus yang dilematis.

VCT memang model pembelajaran yang tidak baru lagi, namun VCT selalu digunakan dalam mendesain pembelajaran yang berpusat pada siswa. Bahar (2008) juga mengungkapkan bahwa VCT merupakan pembelajaran yang sesuai dengan tuntutan perkembangan pembelajaran PKn. Hal ini dapat dimaknai bahwa VCT tetap eksis dan menjadi pilihan guru untuk membuat suasana pembelajaran menjadi hidup.

VCT merupakan pembelajaran aktif yang dapat dijadikan pilihan dalam partisipasi siswa (Lisievici \& Andronie, 2016: 406). Kegiatan pembelajarannya didesain dengan mengacu pada student active learning. Siswa tidak lagi diminta untuk menghafal atau diarahkan untuk memilih hal tertentu. Siswa dibantu untuk memilih, menganalisis, menemukan, sampai pada mempertanggungjawabkan keputusan yang diambil. Peran guru hanya sebagai fasilitator. Guru tidak lagi menyuapi siswa tentang materi-materi, tetapi siswa yang aktif mencari informasi. VCT disajikan melalui diskusi, dialog maupun presentasi.

VCT bukanlah pembelajaran yang kaku, VCT dapat dipadukan dengan metode lain sesuai dengan kebutuhan. VCT dengan bantuan role playing merupakan perpaduan yang menarik. Keduanya merupakan pembelajaran aktif yang menjadi pilihan guru untuk menyampaikan tujuan pembelajaran. Dalam praktiknya, kasus dilematis disajikan melalui role playing sementara langkah-langkah yang lain tetap mengikuti langkah-langkah pembelajaran VCT. 
Joyce, Weil \& Calhoun (2009: 36) mengungkapkan bahwa role playing tidak hanya sekadar bermain peran saja melainkan sarana untuk memecahkan masalah dan merefleksi nilainilai sosial. Senada dengan itu Doorn \& Krosen (2013: 1516) juga menyatakan bahwa role playing tidak hanya mengajarkan siswa untuk mengambil keputusan, lebih dari itu role playing juga mendorong siswa untuk mengambil keputusan secara bijak dan bertanggung jawab. Hal ini tentu sejalan dengan tujuan yang dicapai, yakni membentuk keterampilan sosial anak. Siswa berperan sesuai dengan lakon yang diperankan dalam sebuah kasus dilema moral, setelah itu mereka memecahkan masalah dari kasus yang diperankan.

Hasil penelitian di atas menunjukkan bahwa adanya bantuan Role playing dalam pembelajaran VCT memberikan pengaruh yang positif dalam mencapai tujuan pembelajaran. Keterampilan intelektual siswa dalam mengidentifikasi masalah, menguraikan masalah, menerjemahkan sebuah kasus, menganalisis kondisi, mengevaluasi sebuah kejadian, menentukan pilihan sampai pada mempertahankan argumen tampak lebih unggul jika dibandingkan jika VCT berdiri sendirian.

Efektivitas ini tidak lepas dari perlakuan yang diberikan. Pada kelas eksperimen siswa mendapatkan pembelajaran dengan VCT berbantuan role playing. Siswa tampak memahami stimulus yang diberikan melalui permainan drama. Hal ini tampak berbeda dengan VCT yang disampaikan melalui cerita, masih dijumpai beberapa siswa yang masih belum menangkap isi cerita. Kondisi inilah yang membuat suasana kelas pada kelas eksperimen dan kelas kontrol tampak berbeda. Selain itu, cerita yang disampaikan melalui role playing membuat siswa lebih bersemangat, pembelajaran di kelas menjadi lebih hidup.

\section{SIMPULAN DAN SARAN}

Hasil penelitian menunjukkan bawa pembelajaran PPKn dengan VCT berbantuan role playing lebih efektif dalam membentuk keterampilan intelektual siswa SMA dibandingkan dengan pembelajaran PPKn hanya dengan VCT. Perpaduan kedua metode tersebut merupakan komposisi yang menarik karena sama-sama pembelajaran interaktif. Pada kelas eksperimen tampak siswa lebih antusias dan memahami stimulus jika dibandingkan dengan kelas kontrol.

Guru mata pelajaran PPKn atau mata pelajaran lain dapat menggunakan pembelajaran VCT dengan role playing untuk membentuk keterampilan intelektual siswa SMA. Inovasi pembelajaran perlu dilakukan oleh guru untuk mendapatkan hasil yang maksimal. Keberanian dalam memadukan model pembelajaran adalah salah satu cara untuk mewujudkan inovasi pembelajaran yang lebih menarik.

\section{DAFTAR RUJUKAN}

Adisusilo, S. 2012. Pembelajaran Nilai-nilai Karakter Konstruktivisme dan VCT sebagai Inovasi Pendekatan Pembelajaran Afektif. Jakarta: Rajawali Press.

Agell, L., et al. 2015. Using Role Play to debate animal testing. Journal of Biological Education, 49, 309-321.

Alec, F. 2001. Critical thinking, an introduction, Cambridge, United Kingdom: Cambridge University Press.

Bahar, A. 2008. Penilaian Ranah Afektif Pembelajaran Pkn melalui Model Value Clarification Technique (VCT) permainan. Jurnal Pembelajaran, 30 (1), 121-126

Branson, M.S., et al. 1998. Belajar Civic Education dari Amerika. Terjemahan oleh Syaf- 
ruddin, M. Yasir Alimi \& M. Nur Khoiron. 1998. Yogyakarta: Kerjasama LKIS dan The Asia Foundation.

Cholisin. 2000. Memperkuat Orientasi Keilmuan dan Pemberdayaan Warga Negara sebagai Paradigma Baru Pendidikan Kewarganegaraan Indonesia. Makalah disajikan dalam Seminar on The Need-Assessment for New Indonesian Civic Education, Bandung. Doorn, N. \& Kroesen, J.O. 2013. Using and Developing Role Plays in Teaching Aimed at Preparing for Social Responsibility. Science \& Engineering Ethics, 19, 15131527.

Filiz, K. \& Yasemin, G. 2014. The Effect of Instructional Techniques on Critical Thinking and Critical Thinking Disposition in Online Discussion. Journal of Education Technology \& Society, 17, 248258.

Joyce, B., Weil, M., \& Calhoun, E. 2009. Model of Teaching. Terjemahan oleh Achmad Fawaid \& Ateilla Mirza 2011. New Jersey: Pearson Education.

Kirschenbaum, H. 2013. Values Clarification in Counseling and Psychotherapy. New York: Oxford University Press.

Lisievici, L., \& Andronie, M. 2016. Teachers Assessing the Effectiveness of Values Clarification Techniques in Moral Education. Procedia-Social and behavioral sciences, 217, 400-406.
Oliha, J \& Audu, V.I. 2015. Effectiveness of Value Clarification and Self-Management Techniques in Reducing Dropout Tendency among Secondary School Student in Edo State. European Journal of Education and Development Psychology, 3, 1-13.

Print, M. \& Smith, A. 2000. Teaching Civic Education for a Civil, Democratic Society in the Asian Region. Asia Pacific Education Review, 1, 101-109.

Pusparatri, R. 2012. Strategi Pembelajaran Berbasis Masalah untuk Meningkatkan Kemampuan Berpikir Kritis Siswa. Jurnal Ilmiah Guru, 12, 26-35.

Raths, L., Harmin M., \& Simon S.B. 1978. Values and Teaching. Columbus, $\mathrm{OH}$ : Charles E. Merrill.

Taniredja, T., dkk. 2012. Model-model Pembelajaran Inovatif. Bandung: Alfabeta.

Tim ICCE UIN Syarif Hidayatullah. 2003. Pendidikan Kewargaan: Demokrasi, Hak Asasi Manusia \& Masyarakat Madani. Jakarta: Media Prenada.

Wahab, A. \& Sapriya. 2011. Teori dan Landasan Pendidikan Kewarganegaraan. Bandung: Alfabeta.

Wijayanti, A. 2013. Implementasi Pendidikan Value Clarification Technique (VCT) dalam Pembelajaran IPS Sekolah Dasar. Socia Jurnal Ilmu-Ilmu Sosial UNY, 10, 72-79.

Zuchdi, D. 2011. Pendidikan Karakter dalam Perspektif Teori dan Praktik. Yogyakarta: UNY Press. 